\title{
Digital gangrene associated with anticentromere antibodies: a case report
}

\author{
Lauren Bolster ${ }^{1}$, Regina M Taylor-Gjevre², Bindu Nair² and John A Gjevre ${ }^{3}$
}

\begin{abstract}
Introduction: Anticentromere antibodies have been associated with peripheral vascular occlusive disease, most frequently accompanied by sclerodactyly in the context of a connective tissue disorder. We report a case of digital gangrene with no other clinical associations except positive anticentromere antibodies.

Case presentation: Our patient, a 53-year-old Caucasian woman, non-smoker, presented with progressive pain and blackening of the distal right third finger over the preceding five weeks. No sclerodactyly was evident. She was anticentromere antibody positive at greater than $100 \mathrm{U} / \mathrm{mL}$. Angiography revealed diffuse distal vasculopathy in both upper extremities. Other investigations were unremarkable.

Conclusions: It is rare for anticentromere antibody-associated digital necrosis to develop without concomitant sclerodactyly. However, this patient's case illustrates the need to consider an autoimmune contribution to the pathogenesis of digital ischemia even in the absence of a recognizable connective tissue disease.
\end{abstract}

\section{Introduction}

The presence of anticentromere antibodies (ACA) is most commonly associated with limited scleroderma. To a lesser extent, ACA have been reported in other disorders including: Raynaud's syndrome, Raynaud's phenomenon associated with sclerodactyly, primary biliary cirrhosis (PBC), and Sjogren's syndrome [1-5]. Patients with circulating ACA associated with limited scleroderma or sclerodactyly have been reported to be at increased risk of significant peripheral vascular occlusive disease [6,7]. We report the case of a 53-year-old woman presenting with digital gangrene and a positive ACA without other features of connective tissue disease.

\section{Case presentation}

A 53-year-old Canadian Caucasian woman, who was a clerical worker, presented to her family doctor with a five week history of progressive pain and black discoloration of the distal right third finger. She was initiated on acetylsalicylic acid and warfarin and referred to a regional tertiary care hospital.

\footnotetext{
* Correspondence: r.gjevre@usask.ca

2 Division of Rheumatology, Department of Internal Medicine, University of Saskatchewan, Saskatoon, SK, Canada

Full list of author information is available at the end of the article
}

Her past medical history included depression and a diagnosis of Wolfe Parkinson White (WPW) syndrome, treated since childhood with verapamil. She was taking no other medications. She has never smoked and denied a history of Raynaud's type changes in her digits. Her connective tissue disease review of systems was also otherwise unremarkable.

On examination in the emergency room, there was obvious digital necrosis of the distal right third finger with an adjacent area of pale swollen tissue with ulceration (Figure 1). Allen's test was abnormal with poor refill bilaterally. Capillaroscopic examination of the periungal regions did not reveal dilated capillary loops. No peripheral bruits were audible. A teleangiectasia lesion was evident on the fifth digit. No other skin changes, specifically sclerodactyly, were present. She was admitted to hospital for further investigations and consultation with vascular specialists.

An angiogram revealed evidence of a bilateral obliterative vasculopathic process (Figures 2 and 3). Radiographs of the hands did not reveal any bony abnormality. Further investigations revealed a positive antinuclear antibody with titer $>1280$ and anticentromere specificity. ACA were confirmed by enzyme-linked immunosorbent assay (ELISA) at greater than $100 \mathrm{U} / \mathrm{mL}$. Anti-double stranded DNA, anti-Sjogrens Syndrome A, anti-Sjogrens Syn- 


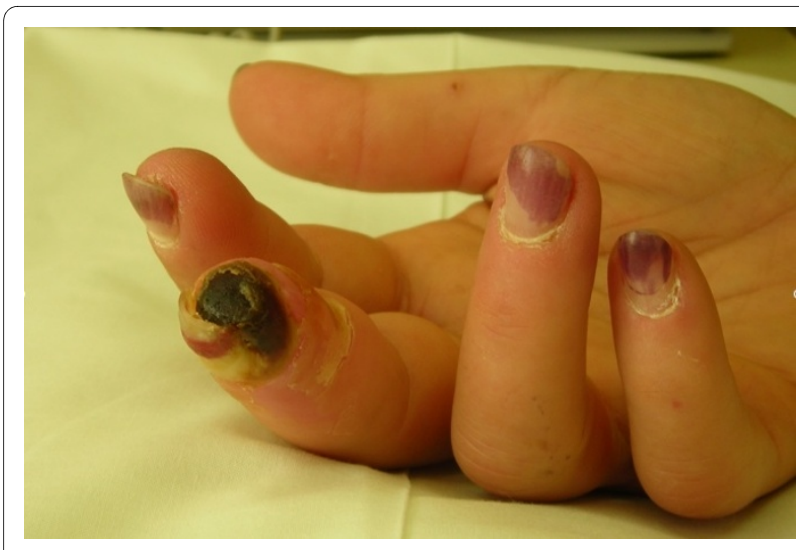

Figure $1 \mathrm{~A}$ photograph of the symptomatic hand demonstrating digital gangrene. The fingernails are discolored from the presence of residual 'gel-nails'.

drome B and anti-ribonucleoprotein antibodies (antiSSA, anti-SSB, anti-RNP), anti-Sm, anti-Scl-70, antineutrophil cytoplasmic antibodies, anticardiolipin antibodies, cryoglobulins, C3, C4, C-reactive protein, complete blood count, electrolytes, creatinine, hepatic transaminases, alkaline phosphatase and urinalysis were all normal or negative. Associated underlying pathology including cardiopulmonary, gastrointestinal and renal involvement were excluded through cardiology consultation, chest radiograph, echocardiogram, pulmonary function testing, high-resolution computerized tomography (CT) of the chest, 24 hour urine for creatinine clearance, serum chemistry and urinalysis, barium swallow, and CT abdomen and pelvis.

In hospital she was initiated on clopidogrel bisulfate, pentoxifylline, topical nitropaste, a two week trial of prednisone, a seven day course of clindamycin and morphine for pain control. Nifedipine was later initiated as an out-patient. Gradually over the next two months the necrosis resolved with minimal tissue loss at the digit tip. She continues to be followed in the rheumatology outpatient clinic with periodic evaluations for potential evolution of connective tissue disease and in cardiology clinic for follow-up of her WPW.

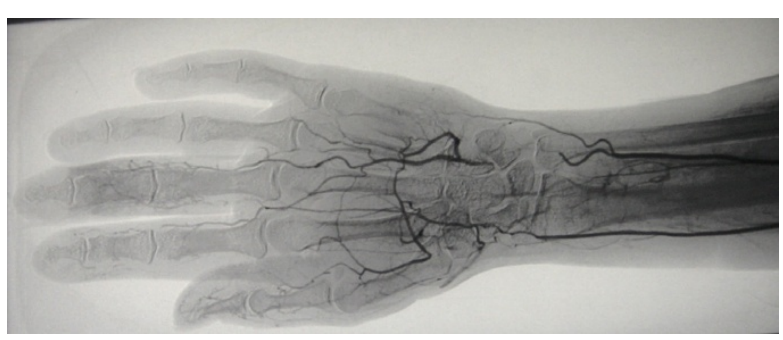

Figure 2 Angiographic image from the right distal upper extremity demonstrating poor distal flow

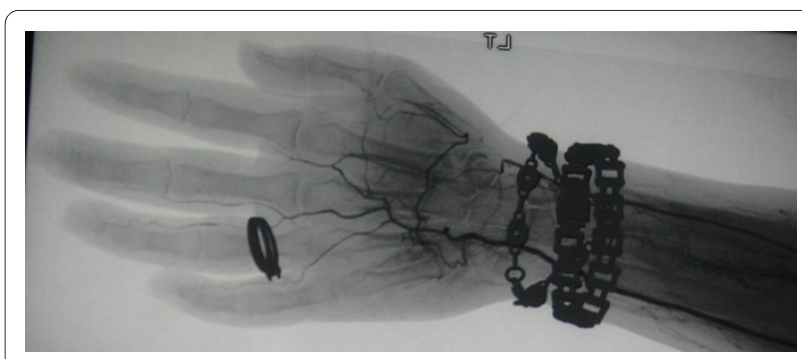

Figure 3 Angiographic image from the left distal upper extremity demonstrating poor distal flow.

\section{Discussion}

The association of ACA with peripheral vasculopathy and digital necrosis has been well recognized in the systemic sclerosis population [8]. This association has also been reported in patients whose disease is on the edge of the systemic sclerosis spectrum with Raynaud's and sclerodactyly alone [1,6]. However, it is most unusual for ACA positive patients without concomitant sclerodactyly to develop digital necrosis $[8,9]$.

In our review of the published literature (Table 1), we observed the majority of reported patients had pre-existing Raynaud's phenomenon recognized well prior to the advent of digital necrosis. Other vascular risk factors including smoking, malignancy or previous thermal injury had also been identified in many of these cases. Our patient is the only case we are aware of in which the digital necrosis presented in isolation.

It has been postulated that ACA, rather than being a marker antibody may have a direct pathogenic role in vascular endothelial injury $[10,11]$. It has been observed that human dermal endothelial cells (HDEC) exposed to sera containing ACA demonstrate increased apoptosis and altered gene expression. These include increased expression of genes linked to apoptosis and development of fibrosis, as well as diminished expression of angiogenesis promoting genes [12]. Sera containing ACA has also been shown to have activity against human umbilical vein endothelial cells [13].

Another point of interest in this patient's history is the coexistence of WPW. In this case, the WPW diagnosis dates back to childhood, and is unlikely to be related to the current presentation. However, development of WPW has been recently reported in a patient with scleroderma siné scleroderma [14]. Gross abnormalities in the conducting system have been demonstrated in systemic sclerosis patients via electrophysiologic testing [15]. It has been hypothesized, that myocardial fibrosis may provide substrate necessary for reentrant tachycardia [16-18]. Potentially anti-endothelial activity in ACA positive sera could influence the development of myocardial fibrosis.

In summary, we present a case of a 53-year-old woman with possible early scleroderma [19] who presents with a 
Table 1: ACA associated digital necrosis without sclerodactyly: a case comparison

\begin{tabular}{|c|c|c|c|c|c|c|c|}
\hline Report & Age (years) & Sex & $\begin{array}{l}\text { Pre-existing } \\
\text { Raynaud's }\end{array}$ & $\begin{array}{l}\text { Raynaud's } \\
\text { duration }\end{array}$ & Region affected & Co-morbidities & Smoker \\
\hline Leon-Perez[20] & $\begin{array}{l}3 \text { cases } \\
(39-62)\end{array}$ & M & Yes $(\times 3)$ & NR & NR & $\begin{array}{c}\text { Past frostbite }(\times 2), \\
\text { HTN }(\times 2)\end{array}$ & Yes $(\times 3)$ \\
\hline Barr[21] & 67 & M & Possible & NR & Fingers & CAD, CAGB & No \\
\hline \multirow[t]{3}{*}{ Takahashi[10] } & 60 & $\mathrm{~F}$ & Yes & 3 months & Fingers, toes & NR & NR \\
\hline & 74 & $\mathrm{~F}$ & Yes & 54 years & Fingers & NR & NR \\
\hline & 79 & $\mathrm{~F}$ & Yes & 30 years & Toes & CVA & NR \\
\hline Picillo[22] & 34 & $\mathrm{~F}$ & Yes & 12 years & Fingers, toe & None & Yes \\
\hline \multirow[t]{4}{*}{ Sachsenberg-Studer[11] } & 43 & $\mathrm{~F}$ & Yes & 2 years & Fingers & None & Yes \\
\hline & 73 & $\mathrm{~F}$ & Yes & 12 years & Fingers & HTN & Never \\
\hline & 84 & $\mathrm{~F}$ & Yes & Unknown & Fingers, toes & HTN & Never \\
\hline & 86 & $\mathrm{~F}$ & Yes & Unknown & Fingers, toe & None & Never \\
\hline Brown[23] & 87 & $\mathrm{~F}$ & No & & Fingers & $\mathrm{CHF}, \mathrm{HTN}$ & Never \\
\hline El Mahou[24] & 72 & M & Yes & NR & Fingers, toes & SCC & Ex-smoker \\
\hline Current case & 53 & $\mathrm{~F}$ & No & & Finger & WPW & Never \\
\hline
\end{tabular}

CABG, coronary artery bypass graft; CAD, coronary artery disease; CVA, cerebrovascular accident; HTN, hypertension; NR, not reported; SCC: small cell lung cancer.

gangrenous digit, occlusive vasculopathy and a positive ACA, without sclerodactyly, a previous history of Raynaud's phenomenon, or other stigmata of connective tissue disease.

\section{Conclusions}

Our patient's case illustrates the need to consider an autoimmune contribution to pathogenesis of digital ischemia even in the absence of a recognizable connective tissue disease. Furthermore, digital ischemia may be the presenting feature or initial manifestation of an underlying evolving connective tissue disease.

\section{Consent}

Written informed consent was obtained from the patient for publication of this case report and any accompanying images. A copy of the written consent is available for review by the Editor-in-Chief of this journal.

\section{Competing interests}

The authors declare that they have no competing interests.
Authors' contributions

LB, RTG, BN and JG all analyzed and interpreted aspects of the clinical data associated with this patient's presentation and implications of the same. LB and RTG reviewed the literature and wrote the manuscript. All authors participated in revising and approving the final manuscript.

\section{Author Details}

'Department of Internal Medicine, University of Saskatchewan, Saskatoon, SK Canada, ${ }^{2}$ Division of Rheumatology, Department of Internal Medicine, University of Saskatchewan, Saskatoon, SK, Canada and 'Bivision of Respirology, Department of Internal Medicine, University of Saskatchewan, Saskatoon, SK, Canada

Received: 28 October 2009 Accepted: 22 June 2010

Published: 22 June 2010

\section{References}

1. Miyawaki S, Asanuma H, Nishiyama S, Yoshinaga Y: Clinical and serological heterogeneity in patients with anticentromere antibodies. J Rheumatol 2005, 32:1488-1494.

2. Fritzler MJ, Kinsella TD: The CREST syndrome: a distinct serologic entity with anticentromere antibodies. Am J Med 1980, 69(4):520-526.

3. Weiner ES, Earnshaw WC, Senecal JL, Bordwell B, Johnson P, Rothfield NF: Clinical associations of anticentromere antibodies and antibodies to topoisomerase I. A study of 355 patients. Arthritis and Rheum 1988, 31(3):378-385 
4. Vlachoyianopoulos PG, Drosos AA, Wiik A, Moutsopoulos HM: Patients with anticentromere antibodies, clinical features, diagnoses and evolution. BrJ Rheumatol 1993, 32(4):297-301.

5. Chou MJ, Lee SL, Chen TY, Tsay GJ: Specificity of antinuclear antibodies in primary biliary cirrhosis. Ann Rheum Dis 1995, 54(2):148-151.

6. Wigley FM, Wise RA, Miller R, Needleman BW, Spence RJ: Anticentromere antibody as a predictor of digital ischemic loss in patients with systemic sclerosis. Arthritis and Rheum 1992, 35(6):688-693.

7. Herrick AL, Heaney M, Hollis S, Jayson MI: Anticardiolipin, anticentromere and anti-Scl-70 antibodies in patients with systemic sclerosis and severe digital ischaemia. Ann Rheum Dis 1994, 53:540-542.

8. Chung L, Fiorentino D: Digital ulcers in patients with systemic sclerosis. Autoimmun Rev 2006, 5(2):125-128.

9. Guiducci S, Giacomelli R, Cerinic MM: Vascular complications of scleroderma. Autoimmun Rev 2007, 6(8):520-523.

10. Takahashi M, Okada J, Kondo H: Six cases positive for anti-centromere antibodies with ulcer and gangrene in the extremities. $\mathrm{Br} J$ Rheum 1997, 36:889-893.

11. Sachsenberg-Studer EM, Prins C, Saurat JH, Salomon D: Raynaud's phenomenon, anticentromere antibodies, and digital necrosis without sclerodactyly: an entity independent of scleroderma? J Am Acad Dermatol 2000, 43:631-634.

12. Ahmed SS, Tan FK, Arnett FC, Jin L, Geng YJ: Induction of apoptosis and fibrillin 1 expression in human dermal endothelial cells by scleroderma sera containing anti-endothelial cell antibodies. Arthritis Rheum 2006, 54(7):2250-2262.

13. Hill MB, Phipps JL, Cartwright RJ, Milford Ward A, Greaves M, Hughes P Antibodies to membranes of endothelial cells and fibroblasts in scleroderma. Clin Exp Immunol 1996, 106(3):491-497.

14. Park YW, Woo H, Yoon HJ, Park HW, Cho JG, Shin SS, et al:: Systemic sclerosis sine scleroderma associated with Wolff-Parkinson-White syndrome. Scand J Rheumatol 2007, 36(1):68-70.

15. Rokas S, Mavrikakis M, Agrios N, Mylonas D, Antoniadou L, Moulopoulos S: Electrophysiologic abnormalities of cardiac function in progressive systemic sclerosis. J Electrocardiol 1996, 29(1):17-25

16. Deswal A, Follansbee WP: Cardiac involvement in scleroderma. $J$ Electrocardiol 1996, 29(1):17-25.

17. Lazzerini PE, Capecchi PL, Guideri F, Acampa M, Galeazzi M, Laghi Pasini F: Connective tissue diseases and cardiac rhythm disorders: an overview. Autoimmun Rev 2006, 5(5):306-313

18. Seferovic PM, Ristic AD, Maksimovic R, Simeunovic DS, Ristic GG Radovanovic G, et al:: Cardiac arrhythmias and conduction disturbances in autoimmune rheumatic diseases. Rheumatology 2006, 45(S4):39-42.

19. LeRoy EC, Medsger TA Jr: Criteria for the classification of early systemic sclerosis. J Rheum 2001, 28(7):1573-1576.

20. Leon-Perez R TN: Digital vasculitis associated with centromere antibodies. Arthritis Rheum 1986, 29:589.

21. Barr WG, Robinson JA: Systemic sclerosis and digital gangrene without scleroderma. J Rheum 1988, 15(5):875-877.

22. Picillo U, Marcialis MR, Matarazzo A, Italiano G, Petti A: Digital gangrene and anticentromere antibodies without scleroderma. Br J Rheum 1998, 37(12):1352-1323.

23. Brown N, Rhys-Dillon CC, Martin JC: Isolated digital infarction associated with anticentromere antibody. Rheumatology 2001, 40:355-357.

24. El Mahou S, Sailler L, Madaule S, Arlet P: RACAND syndrome as a paraneoplastic syndrome? J Clin Rheum 2006, 12(2):104-105.

doi: $10.1186 / 1752-1947-4-189$

Cite this article as: Bolster et al., Digital gangrene associated with anticentromere antibodies: a case report Journal of Medical Case Reports 2010, 4:189

\section{Submit your next manuscript to BioMed Central and take full advantage of:}

- Convenient online submission

- Thorough peer review

- No space constraints or color figure charges

- Immediate publication on acceptance

- Inclusion in PubMed, CAS, Scopus and Google Scholar

- Research which is freely available for redistribution

Submit your manuscript at www.biomedcentral.com/submit
C Biomed Central 